\title{
FROM ROMANIA TO GERMANY: A COMPLEX MOTIVATION OF POST- COMMUNIST ETHNIC MIGRATION. CASE STUDY: GERMANS OF ROMANIA
}

\author{
Silviu Costachie ${ }^{A}$, Dominik Weckmüller ${ }^{B}$, Gheorghe Lixandrescu \\ Received: November 17, 2019 | Accepted: December 20, 2019 \\ DOI: 10.5937/ZbDght1902143C
}

\begin{abstract}
Starting from the Romanian Revolution this article gives an insight to the reasons of emigration movements from Romania to Germany between 1989 and 2017. Different emigration periods are portrayed by regarding the given political events and its effects on the people. Connecting official statistical data and a case study considering reasons, locations, and circumstances, an overview of the diversity of motivation for emigration to Germany is depicted. Furthermore, the role of the German Minorities of Romania, respectively, the Transylvanian Saxons and the Banat Swabs, as an important cohort within the emigrating people, is examined.
\end{abstract}

Keywords: Romanian Emigration; German Immigration; Romanian Revolution; Ethnic Germans of Romania; Poverty Migration.

\section{INTRODUCTION}

The occasion of the $25^{\text {th }}$ anniversary of the German-Romanian treaty of amity 2017 reminds of the rich history between the two countries. Since the middle ages Romania had a strong influence by the Germans. In the $12^{\text {th }}$ century the so called Transylvanian Saxons were enlisted by the Hungarian kings to settle to Transylvania under the permission of certain privileges. Since then, several other German cohorts also settled to Transylvania over the course of time. However, especially $20^{\text {th }}$ century events led to a drastic decrease of the number of Germans in Romania. In 1930 over 633,000 Germans lived in Romania; in 2011 only 36,000 remained (National Institute of Statis-

A Faculty of Geography, University of Bucharest, Bucharest, Romania; contact: silviu_c@yahoo.com

B Faculty of Chemistry and Earth Sciences, Institute of Geography, Heidelberg University, Heidelberg, Germany

c Doctoral School "Simion Mehedinți", University of Bucharest, Faculty of Geography, Bucharest, Romania 
tics Romania, 2012). Between 1990 and 2011 213,000 Germans settled from Romania to Germany as so called late resettlers, or late repatriates (Statistisches Bundesamt, 2016). The territorial changes of World War I, fleeing and recruiting during World War II, discrimination and miserable life circumstances during communism, encouraged not only Germans to settle in Germany (Brubaker, 1994, pp.83-84). The latest numbers of the German Federal Statistical Office (German: Statistisches Bundesamt) show that between 1990 and 2015, more than 1,620,000 people moved from Romania to Germany. Taking into account that there is also a high number of people remigrating to Romania $(1,088,000)$ the balance totals to $+532,000$ persons in Germany (Statistisches Bundesamt, 2016). The latest numbers from 2015 show that more than 213,000 people (Statistisches Bundesamt, 2016) moved from Romania to Germany. Even though almost 127,000 people returned to Romania, it totals to a balance of $+86,000$ people, upward tendency. The Romanian cohort in the German population is currently the fifth largest (Statistisches Bundesamt, 2017).

The Romanian Revolution of 1989 and the end of the communist era opened the gates for an enormous change to a new liberalized economy. However, the transformation from the centrally planned economy to a modern free market economy for many East European countries, and in particular Romania, has proven to be hard to master. Not only the closure of numerous state factories and the inflation of the early 1990s, but also corruption and nepotism were additional obstacles in the process of transformation (Costachie et al., 2015a: 76-80).

With the entry to the European Union in 2007, economic premises have changed and many western companies could set up sites in Romania. With one of the lowest average net nominal earnings of 2,300 Lei (cca. 511 Euro) a month (National Institute of Statistics Romania, 2017), it has become an important site for companies needing a lot of manpower (Costachie et al., 2015b: 67-70).

During the past years, the term 'poverty migration' mostly used in context with South-East European migrants from Romania and Bulgaria created a strongly negative image of Romanian migration in the western societies. Regardless of its implicit meaning and without questioning whether 'poverty migration' exists at all or is a suitable term to describe complex migration it is being reproduced foremost by media as well as the German government itself, i.e. in press conferences or the final report on "Armutsmigration" in 2014 (Bundesministerium des Innern, für Bau und Heimat). Questioning the term and its implication of a high importance of economic reasons of emigration, this study tries to resolve the perceived bias and will show that the reasons are much more diverse and by far not the most important for every cohort.

\section{METHODOLOGY}

For the purpose of investigation, it is necessary to define the category of Romanian emigration. 'Romanian' in this context means people who came during the time of emigration from Romania and used to live there before for at least ten years, or particularly with regard to children, were born and raised in Romania. As it can be seen later, the 
Romanian citizenship opens another category which, within this context, would sophisticate the real state of affairs. This also includes the different German minorities (Wolff, 2001, pp.125-127). Emigration is defined by the Oxford Learner's Dictionary as: 'The act of leaving your own country to go and live permanently in another country' (Oxford Learner's Dictionaries, 2016). Therefore, the investigation solely includes the cohort of people who were born in Romania, hold Romanian citizenship, and permanently left Romania for Germany after the end of the Romanian Revolution on 25 December 1989. In order to gain as many detailed responses as possible and fore mostly gain a broad overview on the diversity of personal motives we chose to create an anonymous online survey. Well aware of broad criticism on inflationary use of surveys in social sciences it is crucial to define its aim before start. Even though they are in some aspects inferior to official statistics or large scale investigations (Gorard, 2003, p. 90), their greatest disadvantage of neither being fully quantitative nor qualitative, they are thoroughly suited to deliver a first insight and a base for further research. Therefore, the following results must not be considered as quantitatively representative but rather as basis to serve for more detailed qualitative or wider quantitative studies.

The chosen survey model is called structured interview (Bernard \& Bernard, 2012, p. 216). The idea is to expose all respondents to the same stimuli respectively questions so the answers are comparable (Bernard \& Bernard, 2012, p. 183). Answers were accepted between 4 March and 24 March 2017. We posted the survey solely on Facebook in specific groups for Romanian people who live in Germany and asked for responses. In addition, we contacted random group members personally through private messages. Furthermore, we posted flyers around the University of Bucharest asking people to spread the survey amongst their contacts. Following questions were proposed in German and Romanian:

1. In which year did you emigrate?

2. In which city did you settle in first?

3. Where do you live now?

4. Do you belong to a certain ethnic group?

5. What reasons did you have to immigrate to Germany?

6. Under which circumstances did you emigrate? Did you have something like a job offer, family or contacts in Germany, or nothing at all?

7. What kind of expectations did you have? (facultative)

8. Do you regret your decision?

9. Do you visit Romania periodically?

10. Space for further information you like to tell me. (facultative)

The total number of given answers is 122 , the number of evaluated answers due to incoherencies of responses is 115. All questions, with the exception of numbers seven and ten were mandatory. Questions one to three were short text categories expecting only the year or the city's name. Knowing that the largest ethnic groups of Germans in Romania were the Transylvanian Saxons and the Banat Swabs, question four could be simplified to four different categories to answer the ethnic belongingness: Swab, Sax, others and none. Allowing to describe one's personal situation entirely, questions five to seven were long text categories permitting whole paragraphs. Questions eight and 
nine were binary, with only a yes or no answer possible. The aim of knowing whether one visits Romania periodically or not, was to get an idea of people still felt Romanian, or were de facto connected to Romania, or whether they dissolved themselves from any kind of allegiance to Romania. Therefore, a detailed time schedule with different increments was of no concern. Anyhow, the different understandings of 'periodically' provide a subjective character which is shrinking the statistical applicability. Finally, question ten was a long text category. For the purpose of gaining as many answers and as much detailed information as possible, we chose to let the user decide how much they chose to write in answer to these long text categories. There was no defined limit. Although the study was a delicate issue, reading the comments of the survey we could ascertain a general positive disposition. Only two people that commented on the posts of the study voiced blatant criticism of the study.

\section{RESULTS}

This chapter contains the results of the study. For each of the ten questions, first, the answers were subjected to mathematical treatment and subsequently statistically analyzed. Furthermore, an idea of their origin is given.

\section{In which year did you immigrate to Germany?}

Concerning the year of emigration, the study displays a distinct result. As it can be seen in Figure 1, after 1989 the year with only four emigrants questioned by our survey, it rose dramatically in 1990 - the year following the Romanian Revolution

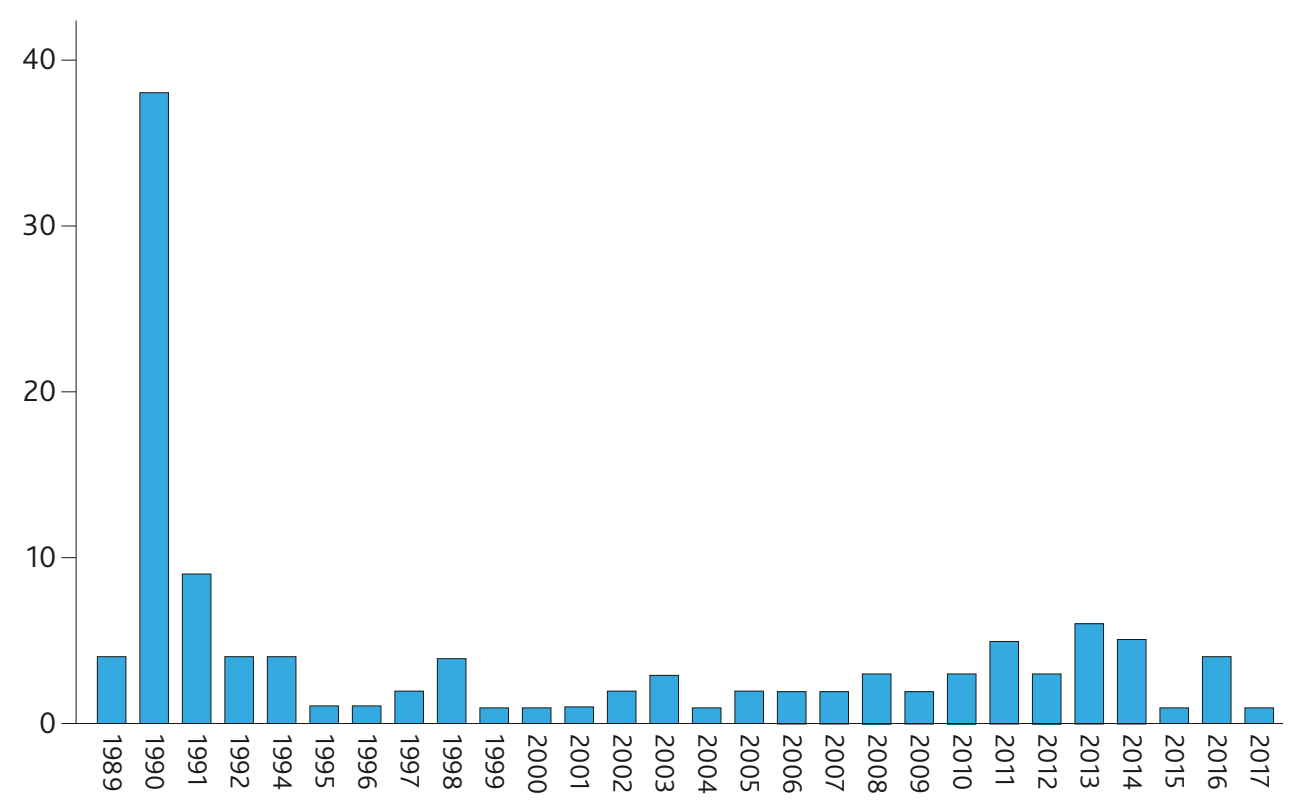

Figure 1. Annual numbers of emigrants from Romania to Germany of the study 
and the opening of the borders. Within this year, 38 people out of the sample of 115 moved to Germany. In 1991 and 1992 the trend flattens with 9 and 4 emigrants, respectively. From the sample there were no responses from people who emigrated in 1993; therewith the peak curve ends. During the next years until 2010 the number of people fluctuates between 1 and 4. From 2011 onwards, there was a light uptrend with a minor peak in 2013 of 6 people. Until 2017, the trend has been decreasing. Considering these results it must be recorded that more than half of the study participants (51.3\%) emigrated in the early years after the revolution until 1994. As the living circumstances during communism were harsh, the suffering population strived for better conditions (Dragomir, 2010: 203-219).

For many people, the December Revolution 1989 represented the turning point. Passports were issued to common citizens so that leaving Romania and settling to Western countries was possible for the first time in decades. Especially discriminated parts of the society like ethnic minorities were literally awaiting the fall of the communist regime and the chance to flee (Ethnocultural Diversity Resource Center, 2005). This explains the fact that most of the study participants emigrated immediately after the revolution.

\section{In which city did you emigrate?}

Figure 2 shows the main locations the people chose to settle after their arrival in Germany. Two noticeable cities can be pointed out: Munich with 22 persons and Bremen with nine. The reason why Nuremberg follows with 4 people is that an emergency reception center especially for Germans of Romania had been installed in the city. A noticeable fact is the even dispersion over the rest of the German cities. Apart from Munich, Bremen and Nuremberg, no city counts more than three immigrants. East Germany having only one immigrant each in Gera and Marienberg, and three immigrants in the capital Berlin, is underrepresented, whereas the north of Baden-Wuerttemberg and the south of Bavar-

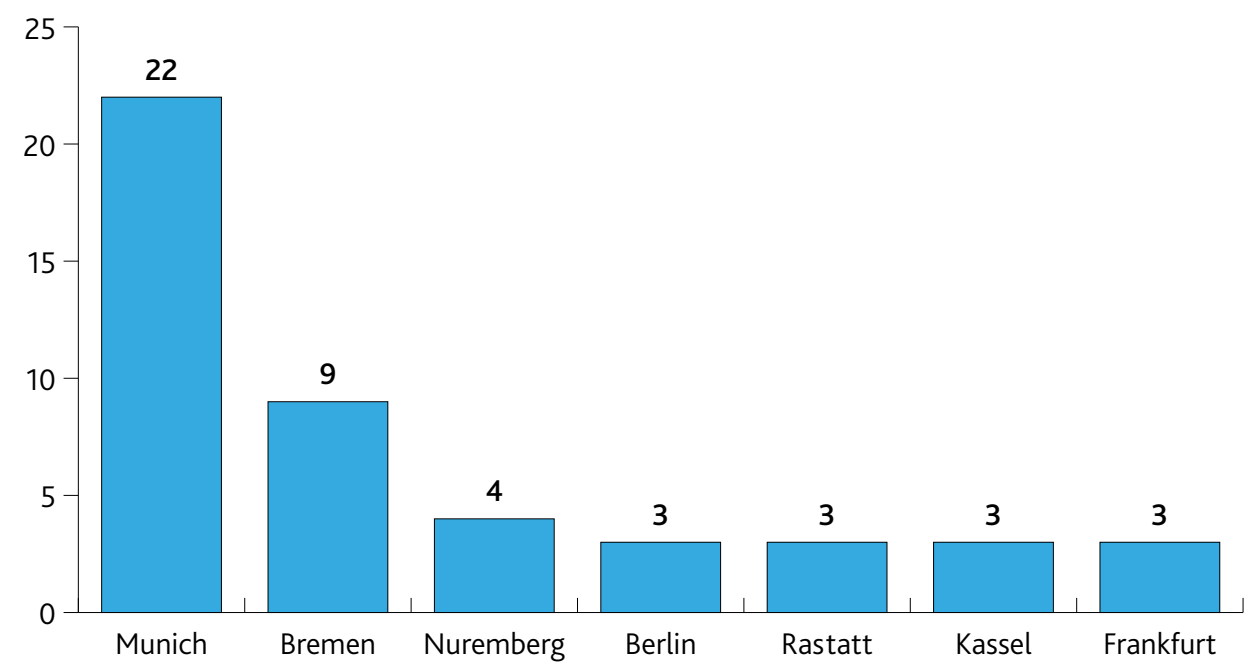

Figure 2. Most chosen cities (more than two times) as cities of arrival by the study participants 
ia was comprised of significantly more immigrants. Even though the Berlin Wall had already fallen before the Romanian Revolution on November 9 1989, the socialist German Democratic Republic (GDR) remained until 3 October 1990, the day of the German reunification. As many people just fled from communism in 1990, the West represented a much more attractive destination as the GDR. Munich seemed to be convenient for many immigrants as it is the closest major city to the eastern border of Germany.

Certain regional allocations can hardly be pointed out. In total, 66 different cities had been chosen.

\section{Where do you live now?}

Compared to the arrival destinations (Figure 2), the current locations (Figure 3) underlie an ambiguous trend. Apart from Munich with 21, no other city counts more than five persons. Berlin and Frankfurt follow with five, Cologne and foreign cities with four, and Ulm, Kassel and Heidelberg with three persons each. Apart from Frankfurt and Kassel, the highest ranked cities of arrival (Munich, Bremen, Nuremberg, Rastatt, Kassel, Frankfurt) disappeared from the top and now home less immigrants. Of the $21 \mathrm{im}$ migrants of Munich, 16 people stayed in the city since they first arrived. The general

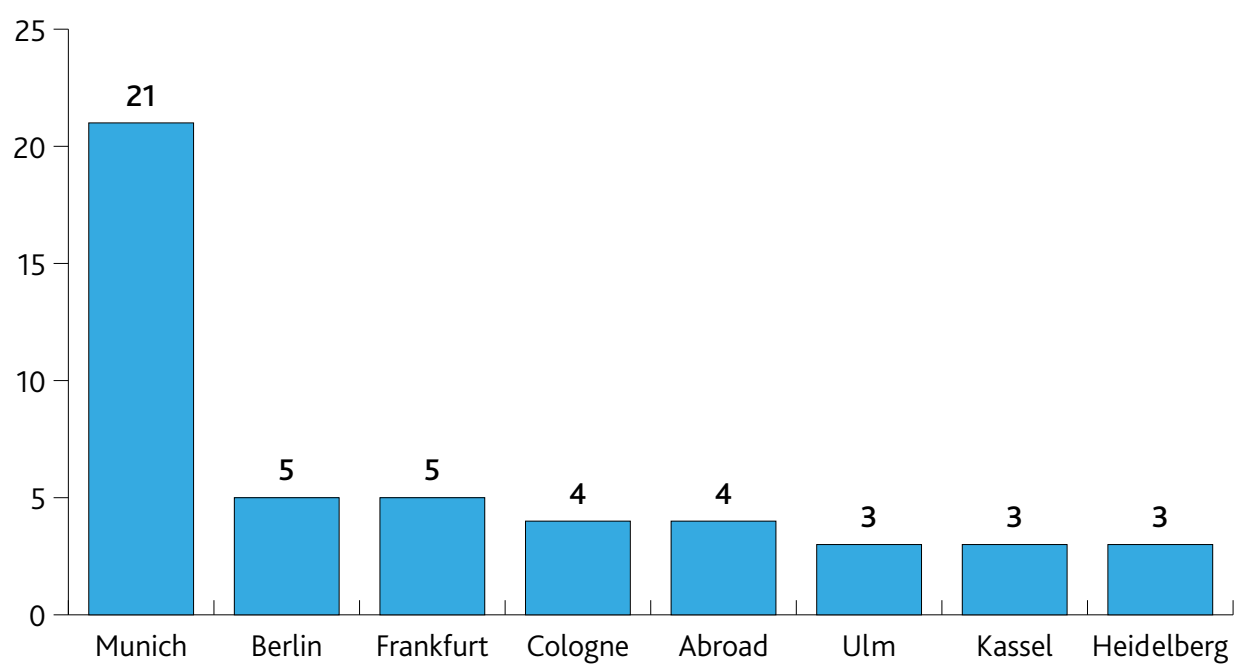

Figure 3. Most chosen cities (more than two times) as current residence

trend of dispersion in Germany continues. In total, 71 cities including four foreign cities had been chosen as the current place of residence. Considering the 2017 ranking of Mercer 'Quality of Living', the high appeal of Munich can be easily explained: in Germany, Munich is the city with the highest quality of living; worldwide it is ranked $4^{\text {th }}$ (Wagner et all., 2017, pp.6).

\section{Do you belong to a certain ethnic group?}

The ethnic belongingness displays the following results: The majority of 62 people (53.9\%) does not knowingly belong to any ethnic group; they shall be called Romanians. 
The German section consists of 51 people (44.3\%), from which 48 people (41.7\%) belong to the group of Transylvanian Saxons and three persons (2.6\%) to the Banat Swabs. Only two other people (1.7\%) chose another ethnicity; one Tartar and one Hungarian participated. This ethnic makeup took place randomly.

\section{What reasons did you have to immigrate to Germany?}

In order to quantify the free answers, it seemed empirically meaningful to divide the free answers into four categories: economic, political, social and personal reasons.

Economic in this context includes everything related to employment. In particular, the acquisition of knowledge in form of apprenticeships, traineeships or studies, generally better salaries, a richer labor market or concrete job offers, but also the absence of these attraction factors in Romania. Out of all answers $30.4 \%$ could wholly or partly be allocated to this category.

Political means everything related to the political situation and political circumstances directly affecting the people's lives. Answers contained different emphases, such as the political situation including open discrimination (especially relevant for the German minority), corruption, nepotism, poor organizational circumstances, less freedom, and home rule. A general attitude of striving for a better future, in particular for their own children, and a better quality of life could be observed.

Social reasons contain aspects such as reuniting family, marriage, social discrimination, lack of social identification with Romania and/or a strong identification with Germany and the people (in particular relevant to Germans), but also peer pressure.

Personal aspects include any remaining answers that could not be allocated to the precedent categories such as the search for experience and adventure, but also medical reasons.

In the following, six different groups are described: all study participants, Romanians only, Germans only, people before 1995, between 1995 and 2006, people after 2006 (Table 1). The answers are divided in different categories where one or more could be chosen. The percentage is related to the total amount of participants expressed by "N".

Table 1. Main results. Percentages of mentioned reasons by all investigated cohorts.

\begin{tabular}{|l|l|r|r|r|r|r|}
\hline \multicolumn{2}{|c|}{} & N & economic & \multicolumn{1}{c|}{ political } & \multicolumn{1}{c|}{ social } & \multicolumn{1}{c|}{ personal } \\
\hline \multirow{3}{*}{ Cohorts } & All participants & 115 & $30.4 \%$ & $47.0 \%$ & $34.8 \%$ & $7.8 \%$ \\
\cline { 2 - 7 } & Romanians & 62 & $41.9 \%$ & $46.8 \%$ & $24.2 \%$ & $11.3 \%$ \\
\cline { 2 - 7 } & Germans & 51 & $15.7 \%$ & $47.1 \%$ & $49.0 \%$ & $2.0 \%$ \\
\cline { 2 - 7 } & $1989-1994$ & 59 & $13.6 \%$ & $47.5 \%$ & $52.5 \%$ & $3.4 \%$ \\
\cline { 2 - 7 } & $1995-2006$ & 21 & $57.1 \%$ & $42.9 \%$ & $19.0 \%$ & $14.3 \%$ \\
\cline { 2 - 7 } & $2007-2017$ & 35 & $42.9 \%$ & $48.6 \%$ & $14.3 \%$ & $11.4 \%$ \\
\hline
\end{tabular}

\subsection{All Study Participants, $N=115$}

Out of 115 participants 35 (30.4\%) mention economic reasons. Within these 35, a number of 9 people (7.8\%) not only mention economic but also other reasons why they moved. 
That means that 26 people (22.6\%) moved solely due to economic reasons. The most quoted reasons of 54 participants (47\%) are political. In particular, the majority of respondents complain about the bad political situation including corruption, and directly mention bribe taking, the nepotistic doings, desperation, intractability, and helplessness. With 40 responses (34.8\%) social reasons are mentioned. Thereunder, the most important reason was family reunification with 26 answers (22.6\%). Nine answers (7.8\%) could not be allocated to the precedent categories. Under these 'Health reasons' are mentioned three times.

\subsection{Romanians only, $N=62$}

Compared to all participants, a significant difference can be observed. Firstly, economic reasons are mentioned by 26 people (41.9\%), this signifies an increase by $11.5 \%$. Out of these 26, $19(30.6 \%)$ are solely economic, whereas eight (12.9\%) mention their studies and nine (14.5\%) mention the salary in addition. Nevertheless, political reasons remain the most important with 29 answers (46.8\%). 15 (24.2\%) mention social reasons, out of which ten (16.1\%) quote family reunification. With seven answers (11.3\%), personal reasons are given.

\subsection{Germans only, $N=51$}

Regarding only the German cohort, consisting of 48 Transylvanian Saxons and three Banat Swabs, an interesting shift can be recorded. Only eight persons (15.7\%) mention economic reasons whereas 24 (47.1\%) moved due to political, 25 (49\%) due to social and only one (2\%) due to personal reasons. Here it is important to mention that while 44 persons (86.3\%) migrated in the early years after the Romanian Revolution between 1989 and 1992, $34(66,7 \%)$ of these were in 1990.

\subsection{Participants between 1989 and 1994, $N=59$}

Looking at the statistics it becomes clear that the migrants in between 1989 and 1994 predominantly did not emigrate due to economic reasons. Only eight answers (13.6\%) fall into that category, whereas 28 (47.5\%) claim political, 31 (52.5\%) claim social, and two (3.4\%) claim personal reasons.

\subsection{Participants between 1995 and 2006, $N=21$}

Out of the small cohort of people between 1995 and 2006, with only 21 responses in total, 12 answers (57.1\%) were predominantly economic reasons, while nine (42.9\%) were political, four (19\%) were social and three (14.3\%) were personal reasons.

\subsection{Participants between 2007 and 2017, N = 35}

From the cohort of 2007 to 2017, 15 (42.9\%) refer to economic reasons. Anyhow, the political reasons prevail with 17 (48.6\%). Social reasons are mentioned by five (14.3\%), and personal by four persons (11.4\%).

\section{Partial Conclusion}

Looking at the results the study displays following ranges. It can be seen that the before 1995 cohort (13.6\%) and the German cohort (15.7\%) have a low tendency for eco- 
nomic reasons whereas the people between 1995 and 2006 have a significantly higher tendency with 57.1\%. Political reasons are throughout stable between $42.9 \%$ and $48.6 \%$. Social reasons vary strongly; with $14.3 \%$ the after 2006 cohort has the lowest tendency for social reasons whereas the before 1995 cohort has the highest with 52.5\%. With the lowest value of $2 \%$ (German cohort) and the highest value of $14.3 \%$ (between 1995 and 2006) personal reasons play a minor role all over the different cohorts. So far it can be stated that out of five different cohorts within the study only one showed a relatively high tendency for economically motivated migration while the others show more diverse reasons and namely political reasons play the most important role.

\section{Possible explanations for study results}

As the main emphasis shall lay on the reasons of migration, this chapter tries to interpret the results and deliver an idea for the circumstances the people lived in and possibly made them migrate.

\section{Economic Reasons}

First of all, the difference between the ethnic cohorts of Germans and Romanians shall be investigated. For that purpose, a closer look on the economies is necessary. Due to the specific and distinct historical development of Transylvania the differences between the Romanian and Transylvanian economies possibly lead to the actual statistical results of the study: while in between 1989 and 2017 15.7\% of the Germans mentioned economic reasons for emigration, the Romanian cohort counts $41.9 \%$ (cf. chapter 3). This may be a sign for a general better economic situation of the German minorities located in Transylvania (Direcţia Treburilor Comitetul Central al Partidul Muncitoresc Român, 1956: 26-31). Historically, during the communist period the Germans even

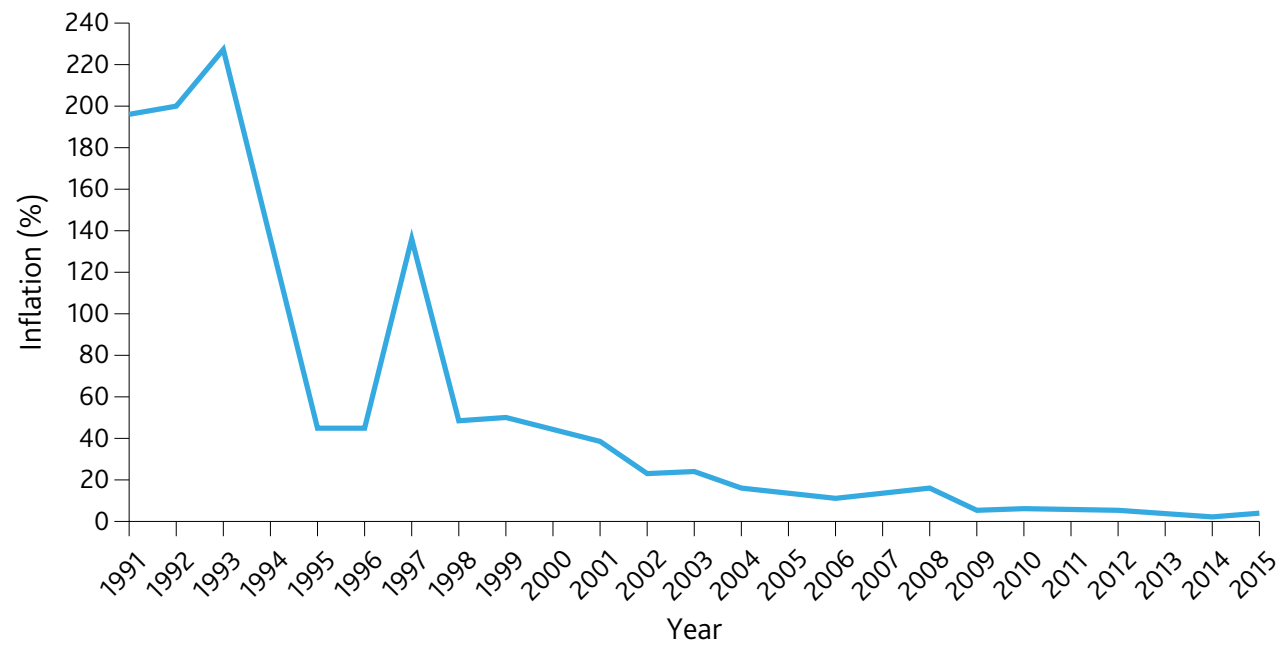

Figure 4: Annual Inflation Rates of Romania 1991-2015.

Data source: World Bank retrieved from http://data. worldbank.org/indicator/NY.GDP.DEFL.KD.ZG?end=2015 Elocations $=$ ROEstart=1991Eview=chart (accessed 10/04/2017) 
though politically discriminated suffered less in monetary issues compared to the Romanian people (Direcţia Treburilor Comitetul Central al Partidul Muncitoresc Român, 1956: 26-31).

Comparing the different chronological measurements, a correlation between the reasons for migration and the general economic development can be spotted. After the Romanian Revolution state companies were privatized and the opening of the economy started. During the early 1990s a record inflation began.

As figure 4 shows, after years of general increasing rates 1993, the As figure 4 shows, after years of general increasing rates 1993 , the peak inflation of $227.3 \%$ was reached. The rate flattened until 1995 to $43.6 \%$ but increased by 1996 up to $135.4 \%$ in 1997. After this second peak, the trend is flattening.

In the first cohort between 1989 and 1994 only 13.6\% mentioned economic reasons; political and social reasons were rather chosen. It is to assume that the second cohort in between 1995 and 2006 suffered the most under the ailing economy and therefore with $57.1 \%$ has a high percentage of economic reasons.

With the beginning of the 21st century, the economic circumstances experienced stabilization through the currency conversion on the 1st of July 2005 and the entry into the European Union. This can be related to the results of the 2007 - 2017 cohort where $42.9 \%$ of the participants mentioned economic reasons for their emigration, which is less than in the 1995-2006 cohort (Cristea et al., 2017: 5-17).

\section{Political reasons}

The Corruption Perception Index 2016 of Transparency International rates Romania on the $57^{\text {th }}$ place out of 176 . On a scale between 0 (highly corrupt) and 100 (very clean) it scored 48 (Transparency International, 2017). According to a Deutschlandfunk Interview of Martin Sieg, director of the offices of the Konrad-Adenauer-Stiftung in Romania and the Republic of Moldova, corruption remains a big issue even though the public authorities combating corruption are under the strongest amongst the post-communist East-European countries. Taking this conflict to the public, the 2017 demonstrations against corruption with temporary over 500,000 participants all over Romania (Frankfurter Allgemeine Zeitung 2017) symbolize not only the peak of these successful demonstrations but also a general attitude of vexation within the Romanian people like for instance the results in the 2006 - 2017 cohort, showing that almost every second participant (48.6\%) claimed political reasons as thriving motivation for their migration. Taking into account, that the people strive for better life circumstances, the 2015 study of the Konrad-Adenauer-Stiftung 2015 'Wie werden die Deutschen in Rumänien wahrgenommen' (How are the Germans perceived in Romania) delivers an idea, why Germany is amongst the most chosen destinations for Romanian Emigrants. Based on computer-aided phone interviews with 1064 persons, it shows a highly positive image of Germans. For example, $84 \%$ regard Germany as the country with the most modern economy of the world, $94 \%$ believe in the role model character and $77 \%$ think that Germany is a trustworthy political partner for Romania (Konrad-Adenauer-Stiftung, 2015), which goes along with a stable political system. 


\section{Social Reasons}

During the communist period in Romania and the beginning of negotiations between Germany and Romania to ransom German people in 1967, more than 123,000 people came to Germany between 1967 and 1989. It is to assume that the majority has been ransomed and only a small part consisted of illegals (cf. chapter 5). This massive exodus could partly explain the high occurrence of social related reasons in the German cohort that came after 1989, as many people already knew someone or had family in Germany by the time of immigrating to Germany.

6. Under which circumstances did you emigrate? Did you have something like a job offer, family or contacts in Germany or nothing at all?

Table 2. Number and percentage of different circumstances. N=115

\begin{tabular}{|l|l|c|c|}
\hline \multicolumn{2}{|c|}{} & Responses N & Percentage \\
\hline \multirow{4}{*}{ Categories } & Family & 64 & $55,7 \%$ \\
\cline { 2 - 4 } & Contacts & 11 & $9,6 \%$ \\
\cline { 2 - 4 } & Work & 13 & $11,3 \%$ \\
\cline { 2 - 4 } & Studies & 11 & $9,6 \%$ \\
\cline { 2 - 4 } & Nothing & 16 & $13,9 \%$ \\
\hline \multicolumn{1}{|l|}{ Total } & 115 & $100,0 \%$ \\
\hline
\end{tabular}

Table 2 shows the results to the question under which circumstances the people emigrated. First of all, $86.1 \%$ had already some kind of contact point, only $13.9 \%$ had neither any kind of occupation nor known people nor relatives in Germany. More than half of all study participants (55.7\%) had family but only $9.6 \%$ had friends or acquaintances in Germany. $11.3 \%$ had a job offer, 9.6\% moved for their studies. The reason for the high family quote is not only the high amount of Germans and their divided families, as explained in the foregoing paragraph. Also, Romanian families are often divided, since family members, most likely men, tend to move to other European countries first and afterwards bring the rest of their families (Cristea et al., 2017: 97-107).

\section{What kind of expectations did you have? (facultative) $\mathrm{N}=108$}

As the question was facultative, out of 115 people 108 answered. Most of these answers remain abstract and evade from being categorized, such as 'that everything is better as in Romania', 'many', 'wanted to start from zero'. Only two concrete answers can be quantified by statistical measurements: 'Better life' quoted by 34 persons (31.5\%) and 'None' by 25 persons (23.1\%).

\section{Do you regret your decision? $\mathrm{N}=\mathbf{1 1 5}$}

A clear majority of 111 persons (96.5\%) does not regret the decision of having gone to Germany. Only four persons (3.5\%), two Romanians and two Transylvanian Saxons, do so. As recent statistics show, concerning the labor market, today Romanians belong to the best integrated foreigner groups in Germany (Institut für Arbeitsmarkt- und Berufsforschung, 2017), which explains the distinct result. 


\section{Do you visit Romania periodically?}

71 study participants $(61.7 \%)$ answered in the affirmative whether they visit Romania periodically whereas 44 persons (38.3\%) answered in the negative. As a certain degree of affection for Romania could be found, it seems logic that these people also visit their motherland periodically.

\section{Space for further information you like to tell me. (facultative)}

The last factitive question was answered by 53 persons. As this question was mainly thought as an open field for everything else, it is of no scientific concern for the study itself.

However, one interesting fact turned out to be statistically measurable. Out of the 53 commentaries, 13 (24.5\%) turned out to be related to a certain degree of pride and affection for their home region in particular Transylvania. Comments such as 'My life is here [in Germany] but my heart is in Romania', 'I am proud to have Transylvanian roots' or 'I still feel affected to Transylvania' show a strong emotional bond.

\section{Official Statistics}

According to the Central Register of Foreigns (Ausländerzentralregister) of The Federal Office of Administration of Germany that captures foreigners by their citizenship, the Romanians with a total account of 533,660 people in 2016 are the fifth biggest group of strangers in Germany towards Turkish $(1,492,580)$, Polish $(783,085)$, Syrians $(637,845)$ and Italians $(611,450)$ (Statistisches Bundesamt 2017). For that reason, it is of interest to take a closer look on the history of this cohort. The development of net migration (Figure 5) shows, that the most significant years of immigration in between 1965 and 2006 started after 1989, the year of the Romanian Revolution. With the fall of the Berlin Wall and therewith the opening of the borders, people could obtain passports and emigrate

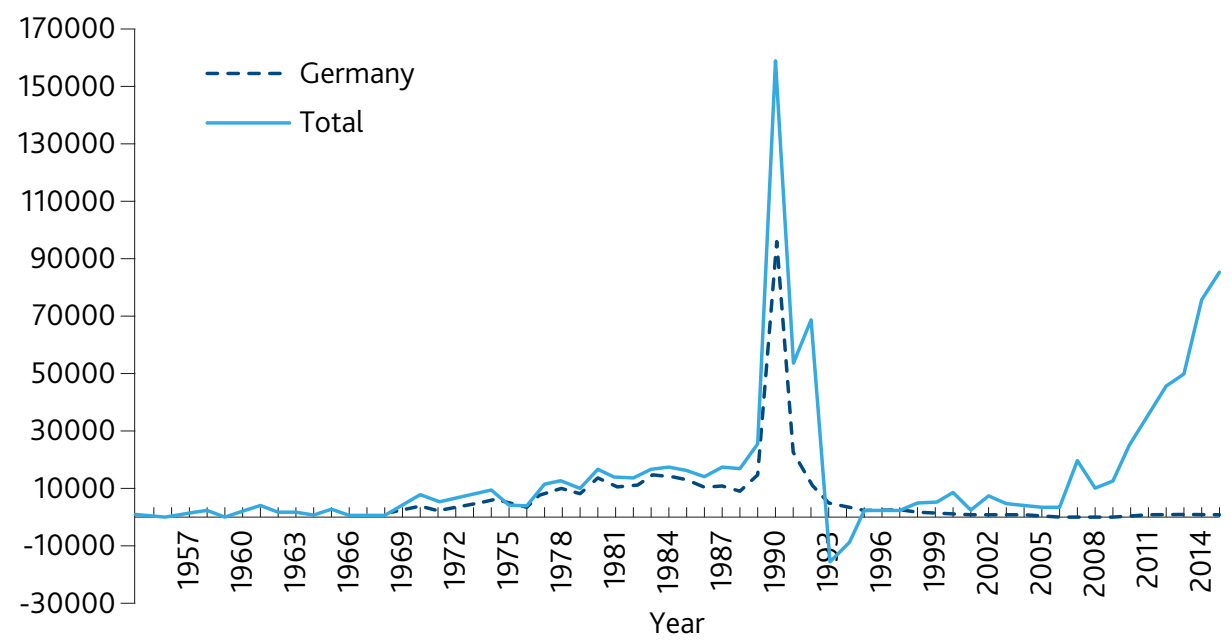

Figure 5: Net Migration between Romania and Germany 1995-2015.

Data Source: Statistisches Bundesamt, Wiesbaden, 2016 Wanderungen zwischen Deutschland und Rumänien 1954 bis 2015. 
to western countries. According to the Statistisches Bundesamt (2016) in 1990, 174,388 persons (96,236 Germans) moved from Romania to Germany. Subtracted by the people that went to Romania it totals to 158,244 (95,843 Germans). The balance for the first three years after the revolution is $+280,623$ people out of which 129,065 Germans came as so called late repatriates (German: Spätaussiedler). The trend flattens after these peak years and due to removing people to Romania became even negative in 1993 and 1994. However, the net migration for Germans after 1998 stays below 1,000 people a year, whereas starting with the entry to the European Union 2007 a sudden increase of nonGermans migrating to Germany can be recognized. The net balance for 2007 is $+19,402$ which increased in 2015 up to 86,274 people. Regarding the latest absolute numbers, a high fluctuation of people can be recognized: in 2015 213,037 people came to Germany while 126,763 went back to Romania. As the graph shows, the granting of full rights of free movement for Romanians on the $1^{\text {st }}$ of January 2014 did not evoke a more rapid growth. Additionally, it is to say that Germany is not gathering ethnic data of the people, which prevents for example to distinguish between Romani and Romanians.

\section{Digression: German emigration during communism in Romania}

The ethnic German immigration to Germany plays a crucial role to the total account of immigrants. The Germans in Romania do not belong to a single group but rather different cohorts, distinguishing in place and period of settlement as well as their origin, traditions, culture and dialects. They can be divided into twelve different groups of which the first two are the biggest and therefore of capital importance - Transylvanian Saxons, Banat, Satmar and Crisana Swabs, Germans of Bessarabia, Bukovina, Dobruja, Bohemia, Bergland, Regat (Oltenia, Muntenia, Moldova), the Carpaths and Transylvanian Landlers. (Vetretungen der Bundesrepublik Deutschland in Rumänien, 2017).

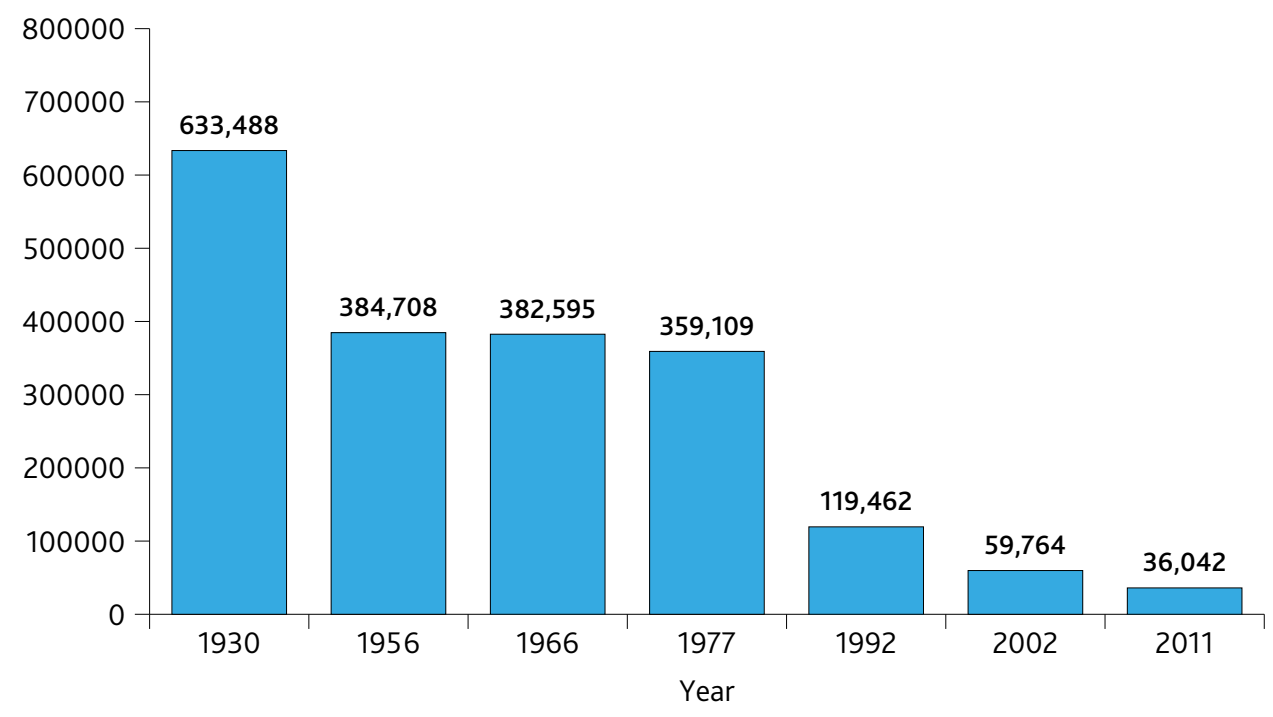

Figure 6. Number of Germans in Romania 1930-2011.

Data Source: Populatia dupa etnie la recensamintele din perioada 1930-2011 - judete INSSE Romania 
During the Ceaușescu regime 1967-1989 the Federal Republic of Germany began negotiations with the Socialist Republic of Romania to ransom ethnic Germans. Under utmost secrecy each year a certain number of Germans would be paid for. According to the Memoirs of Erwin Wickert in 'Die glücklichen Augen' (2001, p.500) first, five value categories between 1,800 and 11,000 German Mark had been set up, increasing with the level of education. Hence starting from 1968 certain people were granted to leave Romania (Baier and Meinhardt, 2014). From 1977 until 1989 each year between 10,000 and 20,000 Germans could settle to Germany. According to the The Federal Office of Administration in the whole period between 1967 and 1989 more than 225,000 Germans were transferred to Germany. Figure 5 shows the number of Germans compared to the total number of emigrants between 1954 and 2015. Due to non-official emigration it is to assume that the real number is even higher. As the official records of the so called 'Geheimsache Kanal' are still under concealment, it is to say that the total numbers are likely vague. Heinz-Günther Hüsch as the main negotiator of Germany said in an interview with the 'Allgemeine Deutsche Zeitung für Rumänien' (Meinhardt, 2009) that he has not seen any correct number related to that case yet apart from Erwin Wickerts releases. By the end of the era of communism with the murder of the Ceausescu, the borders were opened and the treaty between Romania and Germany became obsolete. The total number of Germans in Romania (Figure 6) follows a decreasing trend over a whole century from 1930 with 633,488 Germans until 2011 with only 36,042.

\section{CONCLUSION}

This study delivers an insight in the migration reasons from Romania toward Germany after the Romanian Revolution. As the total number of study participants accounts to 115 people, the results are not wholly representative and therefore try to open a starting point for further research. Anyhow, speaking for this study, it has been shown that the foregoing premise of Armutsmigration in the case of this study must be generally considered as false. Only one investigated cohort (1995 - 2006) shows a high tendency for economic reasons. For this cohort it is important to mention that unmistakably the bad economic circumstances that Romania suffered from after communism, represent the main reason for emigration and not, as the frequently used term poverty migration suggests, morally reprehensible motives like avarice. Additionally, this cohort consists of only 21 people and is therefore less representative. Even though economic and political factors are strongly connected, people tended to make a difference and by far not always mentioned them together. However, the dynamics of reasons are much more diverse and include not only economic but also political, social and personal reasons.

The study displays following results: out of all study participants $30.4 \%$ mentioned economic reasons for their emigration, $47 \%$ political, $34.8 \%$ social and $7.8 \%$ personal reasons. In particular, the political reasons represent the crucial factor.

Within the emigrating different ethnic groups settling to Germany, the most important are the Germans and the Romanians that distinguish highly in their motivation to 
move to Germany. Determining factors for the German cohort is the historically and culturally induced identification with Germany or the non-identification with Romania and social factors like a part of their family already living in Germany. As during the communist era more than 123,000 (Figure 5) people, out of which the majority consisted of ransomed Germans moved to Germany, this represents the main reason for the frequently mentioned social reasons.

Economic reasons for Germans with only $15.7 \%$ are a neglectable factor. On the other hand, Romanians rather mention political and economic dissatisfaction but a low social motivation. Regarding the different chronological cohorts, big differences can be spotted.

The 1989 - 1995 cohort mentioned only 13.6\% economic reasons, but rather political and social reasons with each around $50 \%$ as during this time, most of the Germans (with a high tendency for social factors) emigrated and the political conditions just turned away from communism that shrank people strongly in their freedom.

The 1995 until 2006 cohort is the only investigated cohort where economic reasons are the most important with $57.1 \%$, which can be explained by the bad economy at that time including the all-time high inflation. Anyhow, still $42.1 \%$ complained about a bad political situation, social and personal reasons can be neglected.

The after 2006 until 2017 cohort shows $42.9 \%$ economic and 48.6\% political reasons. Throughout all cohorts the political factors seem the most important. As the KonradAdenauer-Stiftung study shows, Germany is generally perceived as a country where life conditions are much better than in Romania, which still leads to a high rate of Romanians coming to Germany whereas the rate of Germans moving as late repatriates in the past years is extremely low as most of them already immigrated to Germany (KonradAdenauer-Stiftung, 2015).

As a special emigrating cohort, the Germans of Romania show a unique reciprocal way of affiliation. The majority of this cohort immigrated as late repatriates to Germany as they felt connected for different reasons, like family and cultural origins. But those who finally settled to Germany show a high degree of affiliation for their home region in Romania, mostly Transylvania. This phenomenon is widely being investigated under the German term of "Heimat" or most frequently translated as homeland.

This study aims to be an approach to investigate the diversity of reasons and tries to open new perspectives of research for migration studies. Additionally, it tries to deliver a base for the deconstruction of the term "Armutsmigration". For further research we propose both, more detailed quantitative methods respectively larger surveys as well as qualitatively profound methods such as Foucauldian discourse analysis.

\section{SUPERVISION}

This article has been written under the supervision of the Research Center for Regional Development and European Integration of the University of Bucharest and it is the direct result of an annual research program dedicated to emigrational process across Europe. 


\section{REFERENCES}

Baier, H., Meinhardt, E. (2014). Wir haben hart verhandelt. Allgemeine Deutsche Zeitung für Rumänien, 28 and 29 May. Available at: http://www.adz.ro/artikel/artikel/wir-haben-hart-verhandelt/and http://www.adz.ro/artikel/artikel/wir-haben-hart-verhandelt-ii/ (accessed 22 March 2017).

Bernard, H. R. (2012). Social research methods: Qualitative and quantitative approaches. Sage. pp. 260.

Brubaker, R. (1994). Citizenship and Nationhood in France and Germany, Harvard University Press, Cambridge, Massachusetts, USA, pp.83-84.

Bundesministerium des Innern, für Bau und Heimat (2014) Zwischenbericht zur Armutsmigration. Available at https://www.bmi.bund.de/SharedDocs/kurzmeldungen/DE/2014/03/st-ausschuss-zwischenbericht.html (accessed 08.02.2019).

Costachie, S., Damian, N., Paraschiv, V. (2015a) Restructurarea industriei romanesti in perioada postcomunista (I), Academica 2, februarie 2015, anul XXV, 292: 76-80.

Costachie, S., Damian, N., Paraschiv, V. (2015b) Restructurarea industriei romanesti in perioada postcomunista (II), Academica 4, aprilie 2015, anul XXV, 294: 67-70.

Cristea, M., Mare, C., Moldovan, C., China, A., Farole, T., Vințan, A., Park, J., Garrett, K. P., Ionescu-Heroiu, M. (2017) Magnet Cities. Migration and Commuting in Romania, pp.5-17, 97-107. Report World Bank Group, Washington, DC.

Direcţia Treburilor Comitetul Central al Partidul Muncitoresc Român (1956). Referat Privind situaţia populaţiei germane din R.P.R pp. 26-31. Sfera Politicii, 2000, Anul VIII, 83.

Dragomir, E. (2010) Perceptions of Social Security in Communist Romania. Zeithistorische Forschungen/Studies in Contemporary History 2, 2010: 203-219.

Ethnocultural Diversity Resource Center (2005) Minoritati in Tranzitie Raport privind politicile publice in domeniul minoritatilor nationale si etnice din Romania. Report, EDRC, Cluj, January.

Frankfurter Allgemeine Zeitung (2017) 500.000 demonstrieren in Rumänien gegen die Regierung.Available at: http://www.faz.net/aktuell/politik/ausland/proteste-gehenweiter-500-000-demonstrieren-in-rumaenien-gegen-die-regierung-14853880.html (accessed 20 March 2017).

Gorard, S. (2003). Quantitative methods in social science research. A\&C Black. Pp .90-91. Institut für Arbeitsmarkt- und Berufsforschung (2017). Zuwanderungsmonitor. Available at http://doku.iab.de/arbeitsmarktdaten/zuwanderungsmonitor.pdf (accessed 1 May 2017).

Konrad-Adenauer-Stiftung (2015). Wie werden die Deutschen in Rumänien wahrgenommen. Available at http://www.kas.de/wf/doc/kas 40555-544-1-\%2030. pdf?150226194156 (accessed 9 October 2017).

Kahl, T., Schippel, L. (2011). Kilometer Null: politische Transformation und gesellschaftliche Entwicklungen in Rumänien seit 1989. Berlin, Frank and Timme GmbH.

Meinhardt, E. (2009). Fluchtgeschichten. Allgemeine Deutsche Zeitung für Rumänien 23 and 24 December available at https://web.archive.org/web/20100323093110/http:// www.adz.ro/m09122.htm. (accessed 22 March 2017). 
Mercer (2017). München bietet die beste Lebensqualität in Deutschland. Available at https://www.mercer.de/our-thinking/muenchen-bietet-die-beste-lebensqualitaet-indeutschland.html (accessed 4 April 2017).

National Institute of Statistics Romania (2017). Average Gross Earnings on Total Economy were 3168 Lei in January 2017. Available at http://www.insse.ro/cms/sites/default/ files/com_presa/com_pdf/cs01e17.pdf (accessed 23 March 2017).

National Institute of Statistics Romania (2013). PRESS RELEASE Nr.159 July 4th, 2013 on the final results of Population and Housing Census-2011 (demographic characteristics of population). Available at http://www.recensamantromania.ro/wp-content/uploads/2013/07/Press-release-no-159_2011-Population-census-rezults.pdf (accessed 23 March 2017).

Oxford Learner's Dictionaries (2016). Emigration. Available at http://www.oxfordlearnersdictionaries.com/definition/english/emigration?q=emigration (accessed 11 March 2017).

Statistisches Bundesamt (2014). Wirtschaft und Statistik Juni 2014. Available at https://www.destatis.de/DE/Publikationen/WirtschaftStatistik/Monatsausgaben/ WistaJuni2014.pdf;jsessionid=4D2129F86364878F45B61055BE020144.cae3? blob=publicationFile (accessed 9 October 2017).

Statistisches Bundesamt (2016). Wanderungen zwischen Deutschland und dem Ausland nach der Staatsangehörigkeit 1962-2015. Statistisches Bundesamt Destatis, Wiesbaden.

Statistisches Bundesamt (2017). Ausländerzentralregister. Available at https://www. destatis.de/DE/ZahlenFakten/GesellschaftStaat/Bevoelkerung/MigrationIntegration/Methoden/Auslaenderzentralregister.html (accessed 9 October 2017).

Transparency International (2017). Corruption Perceptions Index 2016. Available at http://www.transparency.org/news/feature/corruption perceptions index 2016 (accessed 24 March 2017).

Vetretungen der Bundesrpublik Deutschland in Rumänien (2017). Ausführliche Informationen zur Geschichte der Deutschen Minderheit in Rumänien. Available at http://www.rumaenien.diplo.de/Vertretung/rumaenien/de/06-Kultur-Bildung/ seite minderheiten.html (accessed 9 October 2017).

Wagner, G., Bruemmer, M., Glemser, A., Rohrer, J., Schupp, J. (2017). Dimension of Quality of Life in Germany: Measured by Plain Text Responses in a Representative Survey (SOEP), in SOEP Papers 893, February 2017, Germany.

Wickert, E. (2001). Die glücklichen Augen: Geschichten aus meinem Leben. München: Deutsche Verlags-Anstalt p.500.

Wolff, S. (2001). German Minorities in Europe. Ethnic Identity and Cultural Belonging, Berghahn Independent Publishing House, New York, USA. 